\title{
Standardization Study of Simplicia and Extract of Calamondin (Citrus microcarpa Bunge) Peel, Quantification of Hesperidin and Antibacterial Assay
}

\author{
Elidahanum Husni*, Friardi Ismed, Dony Afriyandi
}

\section{Elidahanum Husni*, Friardi Ismed, Dony Afriyandi}

Faculty of Pharmacy, University Andalas, INDONESIA.

\section{Correspondence}

\section{Elidahanum Husni}

Faculty of Pharmacy, University Andalas, INDONESIA.

E-mail: elidahanumhusni@phar.unand.ac.id

History

- Submission Date: 04-04-2020;

- Review completed: 23-04-2020;

- Accepted Date: 06-05-2020;

DOI : 10.5530/pj.2020.12.111

Article Available online

http://www.phcogj.com/v12/i4

\section{Copyright}

(C) 2020 Phcogj.Com. This is an open access article distributed under the terms of the Creative Commons Attribution 4.0 International license.

\begin{abstract}
Introduction: Calamondin (Citrus microcarpa Bunge) is a commodity which is widely grown in Indonesia, including in western Sumatera. Aim: This study was conducted to Standardization Study of Simplicia and Extract of Calamondin (Citrus microcarpa Bunge) Peel, Quantification of Hesperidin and Antibacterial Assay. Material and Methods: The semi-solid extract of Calamondin peel was made by the maceration method using $70 \%$ ethanol solvent. Then standardization study chamomile extract (Organoleptic examination of extracts, Chromatographic analysis, Total Ash, Acid-insoluble ash, Water content), quantification of hesperidin by TLC-densitometry method and antibacterial activity assay for diffusion method. The antibacterial activity of extracts against Staphylococcus aureus, Escherichia coli, Enterococcus faecalis, and Pseudomonas aeruginous. Results: The organoleptic properties of the calamondin peel showed that the outer surface was brown, and the inside was yellow, slightly smelly, and sour taste. Microscopic characterizations obtained identifiers of calcium oxalate crystal fragments, fibers, parenchyma with oil cells, ladder-shaped transport tissue. Water and alcohol-soluble extractive are not less than $19.73 \% \pm$ $0.97 \%$ and $10.26 \% \pm 0.25 \%$, loss on drying is not more than $10.78 \% \pm 0.05 \%$, and the total and acidinsoluble ash is not more than $4.33 \% \pm 0.03 \%$ and $1.01 \% \pm 0.07 \%$. The calamondin peel extract is described in the form of thick extract, a specific smell, a black color, bitter taste, and yield not less than $25.33 \% \pm 1.3 \%$. Quantification of hesperidin obtained not less than $4.78 \% \pm 0.09 \%$, a water content of no more than $17.47 \% \pm 0.82 \%$, and the total ash content and acid insoluble ash are not more than $4.65 \%$ $\pm 0.06 \%$ and $0.13 \% \pm 0.04 \%$. Antibacterial activity of extracts against Staphylococcus aureus, Escherichia coli, Enterococcus faecalis, and Pseudomonas aeruginous at 15\% concentration with inhibitory diameter range of $7.65 \mathrm{~mm} \pm 0.36 \mathrm{~mm}$ to $9.96 \mathrm{~mm} \pm 0.52 \mathrm{~mm}$ and at a concentration of $20 \%$ with inhibitory diameter ranges of $9.26 \mathrm{~mm} \pm 0.72 \mathrm{~mm}$ to $13.39 \mathrm{~mm} \pm 0.28 \mathrm{~mm}$. Conclusion: Calamondin (Citrus microcarpa Bunge) peel have antioxidant and antibacterial activity

Key words: Antibacterial, Antioxidants, Citrus microcarpa Bunge, Hesperidin, Standardization.
\end{abstract}

\section{INTRODUCTION}

Calamondin (Citrus microcarpa Bunge) is a commodity that is widely grown in Indonesia, even promoted by the One Village One Product (OVOP) of calamondin in Bengkulu'. However, wastewater from calamondins such as peel, pulp, seeds, and extracted water has not been processed into products which has a high sale value $^{2}$. Calamondin contains vitamin C $7.3 \mathrm{gr}$, vitamin A $57.4 \mathrm{mg}$ IU, calcium $8.4 \mathrm{mg}$, water 15.5 gr, potassium $37 \mathrm{mg}$, and fiber $1.2 \mathrm{gr}$. Calamondin peel contains essential oils, $0.15 \%$ ascorbic acid, and $5.5 \%$ citric acid ${ }^{3}$. Calamondin peels and leaves contain about $1.2 \%$ and $0.93 \%$ volatile oil ${ }^{4}$. The study results of Cheong et al., dichloromethane and hexane extracts from calamondin, identified 79 compounds representing $98 \%$ of compounds that evaporate with $\mathrm{N}$-methylantranylate were the most detected compounds. Methanol extract contains a lot of phenolic acids, especially p-Coumaric and ferulic acid ${ }^{5}$. The study results of Bhat et al., stated that calamondin contains flavonoids around 1.41 $\mathrm{mg} / 100 \mathrm{~mL}$ with antioxidant capacity around 777 $\mathrm{mg} / 100 \mathrm{~mL}$ and ascorbic acid around $40.2 \mathrm{mg} /$ $100 \mathrm{~mL}^{6}$. The main flavonoid found in calamondin is hesperidin ${ }^{7}$. Hesperidin has been shown to have antioxidant, anti-cancer, and anti-inflammatory activity $^{8}$. One of the potentials of hesperidin can be developed as a chemotherapy drug because it has been known to have a cytotoxic effect. The research of Adam et al., showed that hesperidin can increase the cytotoxic effect of doxorubicin'. The combination of hesperidin and vitamin $\mathrm{C}$ can overcome blood flow disorders and accelerate the healing of bruises ${ }^{10}$. Hesperidin has anti-hyperglycemic potential and improves heart function in mice with type two diabetes mellitus ${ }^{11}$, an antibacterial activity, such as against Helicobacter pylori ${ }^{12}$.

The community widely likes this plant as a flavoring and scented food and drink in Indonesia ${ }^{13}$. Almost all parts of the calamondin has the potential as a medicine. The methanol extract of the leaves has efficacy as an anti-inflammatory and inhibits the growth of E.coli, Citrobacter freundii, Aeromonas hydrophila, P.aeruginosa, S.agalatiae, and Yersinia enterocolitica ${ }^{14}$, an antioxidant activity and has anti-inflammatory activity ${ }^{15}$. Calamondin juice can stimulate appetite, improve digestive disorders, reduce blood pressure and cholesterol ${ }^{16,17}$.

Monographs on calamondin peels are still minimal. Therefore, it is necessary to standardize specific and non-specific parameters and determine levels of hesperidin which is the identity compound of calamondin. Specific parameters are aspects of 
qualitative chemical content and quantitative aspects of the levels of chemical compounds that are directly responsible for certain pharmacological activities, while non-specific parameters are useful for maintaining compound content, safety, and stability of extracts to have a safety and efficacy consistency in consumers ${ }^{18}$. Because hesperidin has been shown to have antibacterial activity, so researchers are interested in testing the antibacterial activity of the calamondin peel extract against the bacteria S.aureus, E.coli, E.faecalis, and P.auruginosa. $P$. auruginosa and E. coli represent Gram-negative bacteria whereas $E$. faecalis and S. aureus represent Gram-positive bacteria

\section{MATERIAL AND METHOD}

\section{Place and time}

The research conducted in two months in April-September 2019. The preparation and extraction of calamondin peel to determinating the standardization from calamondin peel's extract were conducted in three weeks at Sumatra Biota Laboratory Andalas University.

\section{Tools and materials}

The tools used in the research were Rotary evaporator $\left(\right.$ Buchi $\left.^{\circledR}\right)$, sonicator $\left(\right.$ Elma $\left.^{\circledR}\right)$, analytical scales $\left(\operatorname{Kern}^{\odot}\right)$, curs, vaporizer cup, desiccator, chromatographic vessel, aluminium foil, microscope (Bel Engineering ${ }^{\circledR}$ ), cover and slide glass, filter paper (Whatman ${ }^{\mathrm{Tx}}$ ), measuring flask $\left(\right.$ Pyrex $\left.^{\star}\right)$, measuring cup (Pyrex $\left.{ }^{\circledR}\right)$, UV lamps 254 and $366 \mathrm{~nm}$, UV-Vis spectrophotometer (Shimadzu ${ }^{\circ}$ ), capillary tube, TLC Scanner $\left(\mathrm{Camag}^{\circledR}\right)$, grinder, oven $\left(\mathrm{Memmert}^{\circledR}\right)$, furnaces (1500 furnaces Barnstead thermolyne $e^{\oplus}$, micropipettes (Biokit proline ${ }^{\circ}$ ), tweezers, Laminar Air Flow (LAF) (Biobase ${ }^{\star}$ ), paper discs, autoclaves (All American $^{\circledR}$ ), hot plates, magnetic stirrers, ose needles, long bars, Petri dishes, corn yarn, spatel, cotton, gauze, vortex $\left(\right.$ Etech $\left.^{\circledR}\right)$, plastic wrap, spiritus lamps, standard glassware.

The materials used in the research were calamondin peel, Ethanol $\left(\mathrm{Merck}^{\circledast}\right)$, aqua dest, hesperidin, hydrochloric acid $\left(\right.$ Merck $\left.^{\star}\right)$, chloral hydrate, chloroform $\left(\right.$ Merck $\left.^{\circledR}\right)$, toluene $\left(\right.$ Merck $\left.^{\circledR}\right)$, ethyl acetate $\left(\right.$ Merck $\left.^{\circledR}\right)$, formic acid $\left.\left(\mathrm{Merck}^{\star}\right)\right)$, citroborate, Silica gel 60 F254 plate $\left(\mathrm{Merck}^{\star}\right)$, Nutrient Agar (NA) (Merck ${ }^{\circledR}$ ), physiological NaCl, Mc Farland Solution, dimethyl sulfoxide (DMSO), Test microbes: Staphylococcus aureus ATCC 25923, Escherichia coli ATCC 25922, Enterococcus faecalis ATCC 29212, and Pseudomonas auruginosa ATCC 27853

\section{Extracting}

Calamondin peel is sorted wet, then dried at $45^{\circ} \mathrm{C}$. Simplicia is made into powder using a grinder. Simplicia powder macerated using $70 \%$ ethanol for a day. Then filtered using filter paper and the filtrate was concentrated using a rotary evaporator, to obtain a thick extract. The rendemen obtained is the weight percentage $(\mathrm{w} / \mathrm{w})$ between the extract obtained and the weight of the simplicia used.

\section{Simplicia and extract standardization ${ }^{19,20}$}

1. Organoleptic properties: Identifying simplicia include color, appearance, size, surface properties, texture, and shape of the crosssection.

2. Microscopic characterizations: Identifying the simplicia powder identification fragment using aqua dest and chloral hydrate reagents.

3. Loss on drying: Simplicia powder of 1-2 grams is put into a weighing bottle that has been measured. Smooth over the simplicia powder in the weighing bottle. Then dry it at $105^{\circ} \mathrm{C}$ in an open container using an oven until the weight remains.

4. Total Ash: The simplicia powder or extract of 2-3 grams is inserted into the curs that has been measured, then incandesce sample until the charcoal is used up. Ash content is expressed in $\% \mathrm{w} / \mathrm{w}$.
5. Acid-insoluble ash: Ash obtained from determination of total ash content was boiled with $25 \mathrm{~mL}$ of $2 \mathrm{~N} \mathrm{HCl}$ for 5 minutes. Collect insoluble acid parts, filter using ash-free filter paper, wash with hot water, incandesce ash until the weight remains. Acid insoluble ash content is expressed in $\% \mathrm{w} / \mathrm{w}$.

6. Alcohol-soluble extractive: Simplicia powder of about 5 grams that have been dried in the air. Put in the clogged pumpkin, add $100 \mathrm{~mL}$ of ethanol-water, shake it repeatedly for the first 6 hours and leave it for 18 hours. Then strain and evaporate $20 \mathrm{~mL}$ of the filtrate to dry in a vaporizer cup that has been incubated at $105^{\circ} \mathrm{C}$ until the weight remains.

7. Water-soluble extractive: Simplicia powder of about 5 grams that have been dried in the air. Put in the clogged pumpkin, add $100 \mathrm{~mL}$ of saturated chloroform water, repeatedly shake for the first 6 hours and leave it for 18 hours. Then strain and evaporate $20 \mathrm{~mL}$ of the filtrate to dry in a vaporizer cup that has been incubated at $105^{\circ} \mathrm{C}$ until the weight remains.

8. Water content: Weigh the extract which is estimated to contain 1-4 $\mathrm{mL}$ of water put in a dry flask. For substances that can cause sudden fluctuation when boiling add a boiling stone. Add about $200 \mathrm{~mL}$ of water-saturated toluene to the flask, heat the flask carefully for 15 minutes. After the toluene boils, set the distillation to about two drops per second until most of the water is distilled and increase the distillation speed to 4 drops per second. After all the water has been distilled, the inside of the condenser is washed with water-saturated toluene while cleaning with a tube brush connected to a copper wire and soaked with water-saturated toluene. Continue distillation for 5 minutes. Cool the receiver tube to room temperature. If there are drops of water attached, rub the coolant tube and receiver tube with rubber that is attached to a copper wire and moistened with water-saturated toluene until the water drops drop. Read the volume of water after the water and toluene separate. Water content is calculated in $\% \mathrm{v} / \mathrm{w}$.

9. Chromatographic analysis: The material used in this work is the 60 F254 silica gel plate as the stationary phase and ethyl acetate: formic acid: water (100: 15: 17) as the mobile phase. The test solution is an extract with a concentration of $5 \%$ in $2 \mathrm{ml}$ of aqua dest and sufficient methanol up to $10 \mathrm{ml}$. The comparison used was hesperidin with a concentration of $1000 \mu \mathrm{g} / \mathrm{ml}$ in a suitable solvent. Then, $5 \mu \mathrm{l}$ of the test solution and $5 \mu \mathrm{l}$ of the comparison were made spots on the TLC plate using capillary tubes. The TLC plate is placed on a buffer rack until the making spots station is located below and put into the vessel until it reaches the bottom absorbent layer where the spots is not submerged. The vessel is closed and left until the mobile phase propagates to the limit at the creepage distance. Then, the TLC plate is removed from the vessel and dried. Blemish detection under UV light with a wavelength of $365 \mathrm{~nm}$.

\section{Quantification of hesperidin by TLC-densitometry method $^{21}$}

1. Determination of the maximum wavelength of absorption of hesperidin: $10 \mathrm{mg} / \mathrm{ml}$ hesperidin solution was determined for its maximum absorption wavelength using a UV-Vis spectrophotometer.

2. Preparation of calibration curve: Perform TLC on the comparison made in concentrations of 50,100,150, 200, 250, 500, and 1000 ( $\mu \mathrm{g} /$ $\mathrm{mL}$ ) make spots with a volume of $5 \mu \mathrm{l}$ each. Then, it is scanned using a densitometer with a maximum absorption wavelength. The curve between concentration and AUC that is formed must be linear (R2> 0.99 ) and determine the regression equation.

3. Determination of Hesperidin Levels in Extracts: Scan the TLC plate that has eluted the sample with a concentration of $5 \%$ and comparison 
using a densitometer at its maximum absorption wavelength. Then obtained histogram area data from hesperidin compounds in the test solution (y). The histogram area data of the test compound is entered into the regression equation $y=a+b x$. Thus the level of compound (x) can be determined. This test is carried out using a triple system.

\section{Antibacterial activity assay for diffusion method}

1. Preparation of Nutrient agar (NA) media: Nutrient agar powder as much as 20 grams dissolved with $1 \mathrm{~L}$ aqua dest in Erlenmeyer, then heated on a hot plate using a magnetic stirrer to form a clear solution. Next, it was sterilized in an autoclave at $121^{\circ} \mathrm{C}$ with a pressure of $15 \mathrm{lbs}$ for 15 minutes.

2. Preparation of microbial suspensions: As much as one microbial test loop was taken from pure culture and suspended into sterile physiological $\mathrm{NaCl}$, then homogeneous using a vortex. The turbidity of the suspension is compared using the standard $0.5 \%$ Mc-Farland on a black background and bright light. A $0.5 \% \mathrm{Mc}$-Farland strength standard was created by adding $99.5 \% \mathrm{~mL}$ of $1 \% \mathrm{H} 2 \mathrm{SO} 4$ to 0.5 $\mathrm{mL}$ of $1.175 \% \mathrm{BaCl} 2$ solution. The test extract was dissolved with DMSO solution with concentrations of 15 and $20 \%$. A total of 100 $\mu \mathrm{L}$ of the microbial test suspension was inserted into the petri dish and then added with enough NA media to cover the lower surface of the petri dish and then homogenized. After the solid media is placed, a sterile blank disc that has been dropped $10 \mu \mathrm{L}$ of the test solution. For positive control, chloramphenicol is used. While the negative control was used a sterile blank disc that dropped by $10 \mu \mathrm{L}$ DMSO. The Petri dishes were incubated at $35-37^{\circ} \mathrm{C}$ for $18-24$ hours. Antibacterial activity is positive if there is a barrier zone in the form of a clear zone around the blank disc. Barriers are measured using callipers. The smallest concentration that still shows the clear zone is used to determine the Minimum Inhibitory Concentration (MIC). All tests were done in triplicate.

\section{RESULTS AND DISCUSSION}

In this study, samples were used in the form of calamondin peel from three different regions based on administrative differences (at least districts) in West Sumatera randomly selected, namely Bukittinggi and Padang, and Pesisir Selatan District. The sample is dried in an oven at $45^{\circ} \mathrm{C}$ for several days until the sample is dry. The use of an oven with this temperature to keep the simplicia from impurity and guarantee the quality ${ }^{22}$. Dry samples are then mashed using a grinder so that the simplicia powder is obtained. Furthermore, standardization is performed on simplicia (Figure 1).

The first parameter determined is macroscopic simplicia. This examination is carried out by directly observing the physical form of the simplicia and extract of the calamondin peel, aiming to determine the characteristics of the calamondin peel. The next parameter that is carried out is microscopic observation, which is an examination to identify the identification fragment of the simplicia powder using a microscope to prevent the falsification of the simplicia ${ }^{19}$. The observation is carried out using a microscope at 400 times magnification with a chloral hydrate reagent. The addition of chloral hydrate aims to eliminate the contents of cells such as starch and protein so that other cells can be seen clearly under a microscope. The simplicia calamondin peel had brownish outer surface, and the inside is yellow, slightly smelly and sour taste (Figure 2). Microscopic examination obtained identifiers of calcium oxalate crystal fragments, fibers, parenchyma with oil cells, ladder-shaped transport tissue. Microscopic examination can be seen in Figure 3.

The next step is to determine the simplicia standardization parameters, namely loss on drying. The purpose of the loss on drying parameter is to give a range of magnitude of the lost compound to the drying process ${ }^{23}$.
The missing compound is a volatile compound such as water, essential oils, and others. It is intended that the simplicia is not easy to moldy so it does not affect the chemical content of the simplicia. In addition, loss on drying parameters can be used to ensure the drying process of plants has been carried out perfectly. Loss on drying value of simplicia calamondin peel obtained no more than $10.76 \%$. The next parameter is the determination of water-soluble and ethanol extracts content. Determination of the extract content in certain solvents provides an initial picture of the amount of compounds present in the sample. The water used is chloroform saturated water to avoid microbial growth in the water. Ethanol used is $96 \%$ ethanol. The results of the determination of water-soluble extract content and ethanol-soluble extract content of calamondin peel obtained no less than $19.73 \% \pm 0.97 \%$ and $10.26 \% \pm$ $0.25 \%$. From the results of the percentage of water-soluble and ethanol extract content, it can be concluded that secondary metabolites are
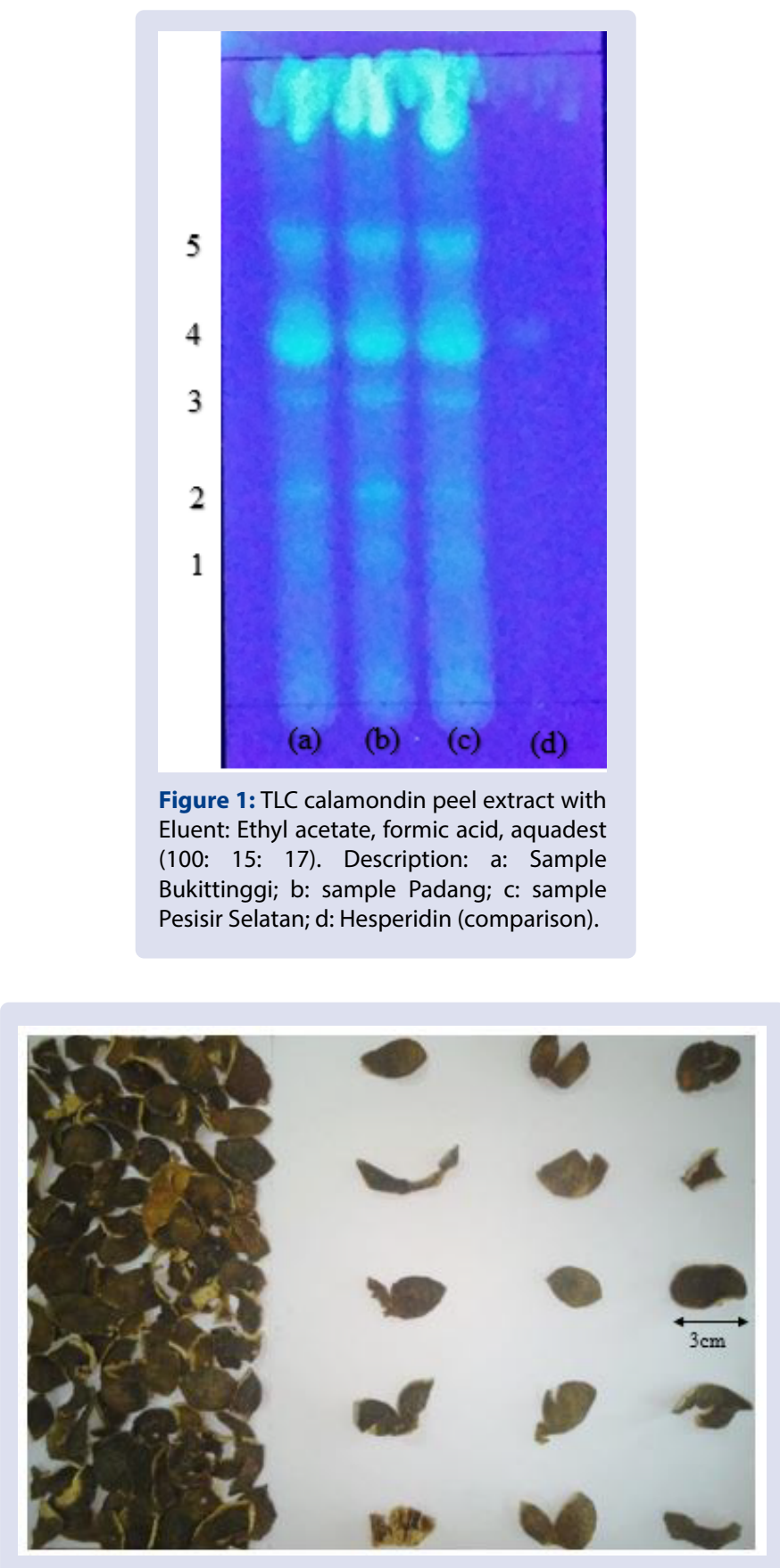

Figure 2: Macroscopic simplicia of calamondin peel. 
found more in water solvents than ethanol solvents. So calamondin simplicia contains a higher polar compound than semipolar-nonpolar compounds. The result of all parameter simplicia can be seen in Table 1.

The extract is made by maceration of simplicia powder by using ethanol solvent because it is able to dissolve almost all substances, both polar, semi-polar and non-polar in nature and can precipitate proteins and inhibit enzymes work so that they can avoid the process of hydrolysis and oxidation ${ }^{24}$. Ethanol used is ethanol $70 \%$ which is commonly used for the extraction of dry samples. Maserat is evaporated under vacuum so that air pressure on the surface is reduced so that the boiling point drops. This condition can reduce the possibility of decomposing the compounds contained in the sample at high temperatures. After evaporating, the extract was obtained not less than $25.33 \% \pm 1.3 \%$. The results of giving calamondin peel extract in the form of thick extract, special odor, black color and bitter taste. The standardization of extracts, the water content was determined. The water content in the extract also determines the stability of the extract, because high water content results in the ease of bacteria, mold, and yeast to multiply so that there will be changes to the extract ${ }^{25,26}$. Determination of extract water content is done by distillation. One of the chemicals that can be used in determining the extract water content is toluene. The use of toluene as a distillation-carrying chemical liquid because toluene has a boiling point higher than water that is $110^{\circ} \mathrm{C}$, and toluene cannot mix with water because toluene is non-polar while water is more polar and toluene has a lower specific gravity than water that is $0.867 \mathrm{gr} / \mathrm{mL}$. In addition, the use of toluene is intended so that fats do not evaporate when distilled because non-polar fats will dissolve in toluene which is also a non-polar solvent ${ }^{27}$. Water content obtained from the extract of the calamondin peel is not more than $17.47 \% \pm 0.82 \%$. The result of all parameter extract can be seen in Table 1 .

The next parameter in extract standardization is TLC. The TLC profile is a qualitative analysis to show the presence of certain marker compounds present in the sample and to describe the composition of the chemical compounds contained in the sample. The TLC profile of the ethanol extract of calamondin peel used the comparative compound hesperidin. It is because hesperidin is a compound that is mostly contained in oranges ${ }^{28}$. In detecting patches of hesperidin, citroborate stain reagents are used, assisted with heating and detected by UV with wavelength $365 \mathrm{~nm}$. Citroborate is used as a stain-viewer to identify flavonoid compounds ${ }^{29}$. The results of TLC calamondin peel extract was Rf1: 0.34; Rf2:0.43; Rf3: 0.58; Rf: 0.68 and Rf5: 0.78 while hesperidin (comparison) Rf was 0.68 . From this pattern, it can be concluded that hesperidin is found in the calamondin peel extract (Figure 3).

Other parameters in the standardization of simplicia and extracts are a determination of total ash content and acid insoluble ash content. Determination of total ash content aims to provide an overview of the internal and external mineral content and organic matter originating from the initial process until the extract is formed. Determination

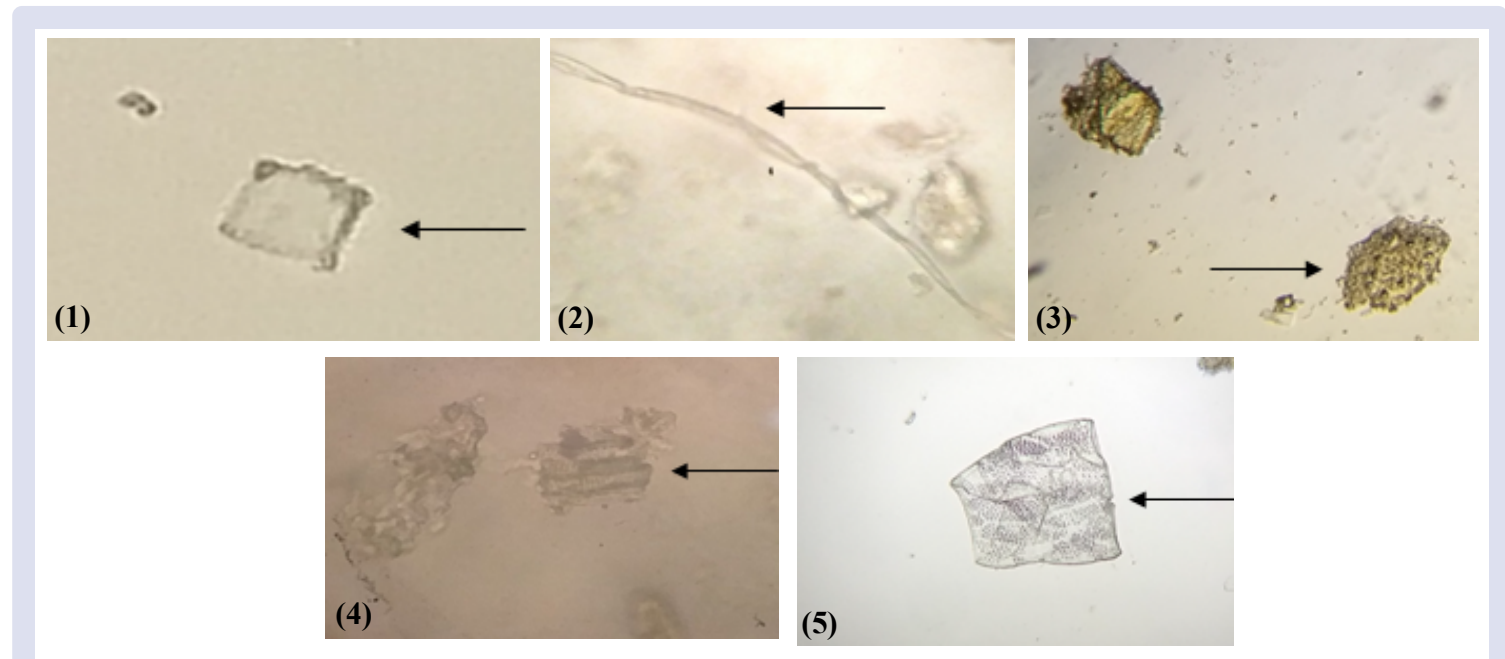

Figure 3: Microscopic simplicia of calamondin (1) calcium oxalate crystal (2) fibers (3) parenchyma with cells oil (4) laddershaped transport tissue (5) crystalline parenchyma calcium oxalate.

Table 1: Simplicia standardization data and calamondin peel extract.

\begin{tabular}{|c|c|c|c|c|c|}
\hline \multirow{2}{*}{ Sample } & \multirow{2}{*}{ No } & \multirow{2}{*}{ Standardization parameter } & \multicolumn{3}{|c|}{ Results (\%) } \\
\hline & & & Pesisir Selatan & Padang & Bukittinggi \\
\hline \multirow{7}{*}{ Simplicia } & & & Specific Parameters & & \\
\hline & 1 & Water Soluble extractive & $23.06 \pm 0.44$ & $19.73 \pm 0.97$ & $21.89 \pm 0.77$ \\
\hline & 2 & Alcohol Soluble extractive & $14.49 \pm 0.38$ & $11.08 \pm 0.9$ & $10.26 \pm 0.25$ \\
\hline & & & Non Specific Parameters & & \\
\hline & 3 & Loss on Drying & $5.15 \pm 0.06$ & $4.83 \pm 0.28$ & $10.78 \pm 0.05$ \\
\hline & 4 & Total Ash Content & $4.33 \pm 0.03$ & $4.31 \pm 0.05$ & $4.06 \pm 0.03$ \\
\hline & 5 & Acid insoluble ash content & $0.94 \pm 0.1$ & $1.01 \pm 0.07$ & $0.95 \pm 0.15$ \\
\hline \multirow{6}{*}{ Extract } & & & Specific Parameters & & \\
\hline & 1 & Hesperidin levels & $4.78 \pm 0.09$ & $5.23 \pm 0.23$ & $5.58 \pm 0.24$ \\
\hline & & & Non Specific Parameters & & \\
\hline & 2 & Rendemen & 25.33 & 27.93 & 26.82 \\
\hline & 3 & Total Ash Content & $2.61 \pm 0.06$ & $4.65 \pm 0.06$ & $3.78 \pm 0.43$ \\
\hline & 4 & Acid insoluble ash content & $0.1 \pm 0.02$ & $0.12 \pm 0.02$ & $0.13 \pm 0.04$ \\
\hline
\end{tabular}


of total ash content is done by heating at high temperatures where the organic compounds and their derivatives are decomposed and evaporated at a temperature of $700{ }^{\circ} \mathrm{C}$ until only mineral and inorganic elements remain ${ }^{23}$. Total ash content obtained from simplicia and extract of calamondin peel is not more than $4.33 \% \pm 0.03 \%$ and $4.65 \% \pm 0.06 \%$. Ash obtained from the determination of total ash content is used to determine acid insoluble ash content. Determination of acid-insoluble ash content aims to evaluate the material against contamination of ingredients which contain silica like soil and sand. Acid insoluble ash content obtained from simplicia and extracts calamondin peel no more $1.01 \% \pm 0.07 \%$ and $0.13 \% \pm 0.04 \%$. The result of all parameter of extract can be seen in Table 2 .

The next parameters was determination of chemical content (hesperidin) in the extract. It used TLC-densitometry method with a maximum absorption wavelength of hesperidin was $284 \mathrm{~nm}$. The linear regression of the hesperidin comparison calibration curve for the calculation of hesperidin levels was $y=15.914 \mathrm{x}-49.778$ $\mathrm{R}^{2}=0.996$ and the heperidin level of calamondin peel extract was not less $4.78 \%$. The spectrum $\lambda$ max of hesperidin can be seen in Figure 4 .

Furthermore, the antibacterial activity of the calamondin peel extract was tested using the agar diffusion method. The principle of the agar diffusion method is that the test substance is dripped on a blank disc, then placed on the agar media which has been inoculated by bacteria. The test substance will diffuse into the agar medium, if a clear area is formed around the disc on the media indicating the presence of bactericidal activity by antibacterial agents on the surface of the agar media $^{30}$.
The agar Nutrient Media is chosen because it has complete nutritional content for the growth of bacteria such as peptone, $\mathrm{NaCl}$, yeast extract, and beef extract ${ }^{31}$. The antibacterial activity test of calamondin peel extract was carried out at a concentration of $20 \%$ and $15 \%$ in DMSO. DMSO is used as a test extract solvent because it can dissolve polar and nonpolar compounds ${ }^{32}$. The negative control used is DMSO aimed to prove that DMSO which is to dissolve the test extract does not have antibacterial activity. The positive control used in antibacterial testing is chloramphenicol at $0.3 \%$. Chloramphenicol is used as a positive control because it belongs to a broad spectrum of antibiotics that can inhibit the growth of Gram-positive and Gram-negative bacteria ${ }^{33}$. The test is carried out three times repeated for the accuracy of the test and minimize errors. The bacterial suspension was made in $0.9 \%$ $\mathrm{NaCl}$ solution. $\mathrm{NaCl}$ as a source of bacterial minerals because one of the factors that influence bacterial growth. $\mathrm{NaCl} 0.9 \%$ is used to keep bacterial cells in an isotonic state. $0.9 \% \mathrm{NaCl}$ used must be sterile to avoid contamination of other microbes ${ }^{34}$. Bacterial suspension compared to turbidity using the Mc Farland $0.5 \%$ standard. Cell density of Mc Farland $0.5 \%$ was $1.5 \times 10^{8} \mathrm{CFU} / \mathrm{mL}$. This means that in the bacterial suspension made, it is estimated that there are a number of bacterial cells of $1.5 \times 10^{8}$ cells in each $\mathrm{mL}$ of solution ${ }^{35}$.

The results of the antibacterial activity test of calamondin peel extract from three regions namely Bukittinggi, Padang and Pesisir Selatan against S. aureus, E. coli, E. faecalis, and P. auruginosa at $15 \%$ concentration with inhibitory diameter range of $7.65 \mathrm{~mm} \pm 0.36 \mathrm{~mm}$ to $9.96 \mathrm{~mm} \pm 0.52 \mathrm{~mm}$ and at a concentration of $20 \%$ with a diameter range of $9.26 \mathrm{~mm} \pm 0.72 \mathrm{~mm}$ to $13.39 \mathrm{~mm} \pm 0.28 \mathrm{~mm}$.

Table 2: Test data for antibacterial activity of calamondin peel extract.

\begin{tabular}{|c|c|c|c|}
\hline \multirow{2}{*}{ Sample } & \multirow{2}{*}{ Bacteria } & \multicolumn{2}{|c|}{ Inhibition zone } \\
\hline & & $20 \%$ & $15 \%$ \\
\hline \multirow{4}{*}{ Bukittinggi } & Pseudomonas aeruginosa & $9.70 \pm 0.69$ & $8.58 \pm 0.38$ \\
\hline & Escheria Coli & $11.41 \pm 1.22$ & $9.53 \pm 0.94$ \\
\hline & Staphylococcus auerus & $10.74 \pm 0.43$ & $8.44 \pm 0.57$ \\
\hline & Enterococcus Faecialis & $10.47 \pm 0.71$ & $8.03 \pm 1.02$ \\
\hline \multirow{4}{*}{ Padang } & Pseudomonas aeruginosa & $10.46 \pm 1.43$ & $7.65 \pm 0.36$ \\
\hline & Escheria coli & $10.03 \pm 0.82$ & $8.08 \pm 0.62$ \\
\hline & Staphylococcus auerus & $10.78 \pm 0.93$ & $7.82 \pm 0.81$ \\
\hline & Enterococcus faecialis & $9.79 \pm 0.68$ & $8.37 \pm 0.66$ \\
\hline \multirow{4}{*}{ Pesisir Selatan } & Pseudomonas aeruginosa & $13.39 \pm 0.44$ & $9.96 \pm 0.52$ \\
\hline & Escheria coli & $9.26 \pm 0.72$ & $7.96 \pm 0.65$ \\
\hline & Staphylococcus auerus & $11.18 \pm 0.44$ & $9.39 \pm 1.12$ \\
\hline & Enterococcus faecialis & $10.84 \pm 0.93$ & $8.20 \pm 1.08$ \\
\hline
\end{tabular}

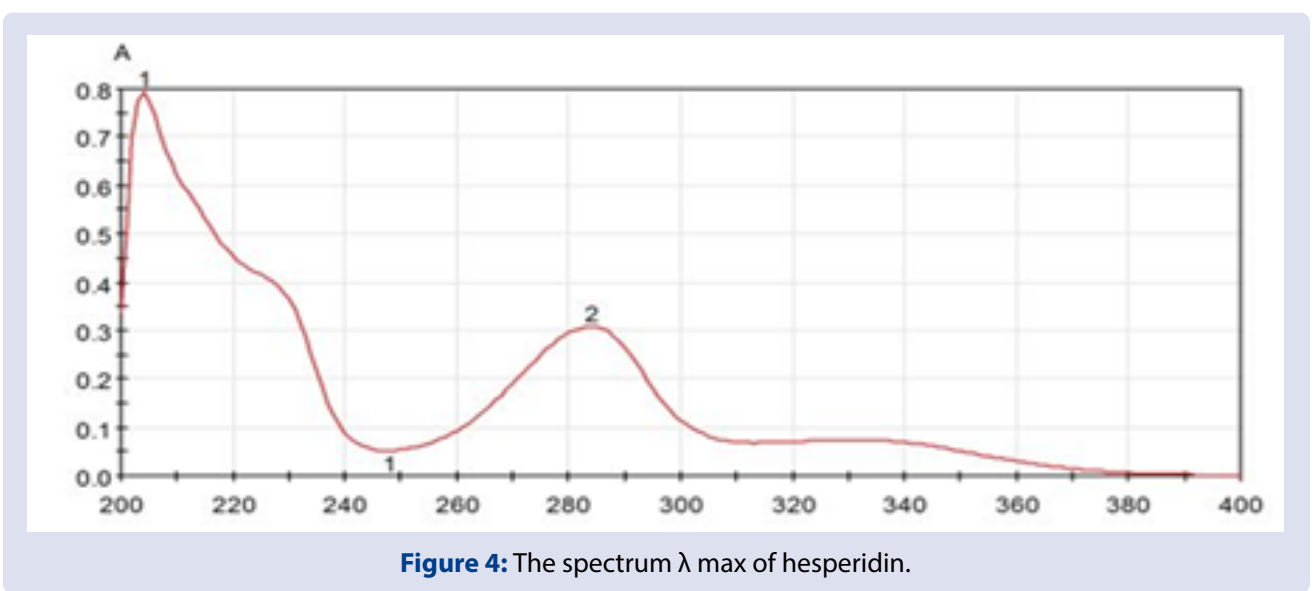




\section{CONCLUSION}

1. The examination results of calamondin peel simplicia (Citrus microcarpa Bunge) are outer surface is brown and the inner is yellow, slightly smell and sour taste. Microscopic examination obtained identifiers of calcium oxalate crystal fragments, fibers, parenchyma with oil cells, ladder-shaped transport tissue. Water soluble extract and ethanol content is not less than $19.73 \% \pm 0.97 \%$ and $10.26 \% \pm$ $0.25 \%$, loss on drying value is not more than $10.78 \% \pm 0.05 \%$, and the total ash content and acid insoluble ash is not more than $4.33 \%$ $\pm 0.03 \%$ and $1.01 \% \pm 0.07 \%$.

2. The examination results of the calamondin peel extract are thick, distinctive smell, black and bitter taste. The TLC pattern used a comparison hesperidin with an Rf value of 0.68 , a hesperidin level of not less than $4.78 \% \pm 0.09 \%$, rendemen value of not less than $25.33 \%$ $\pm 1.3 \%$, a water content of no more than $17.47 \% \pm 0.82 \%$, and the total ash content and acid insoluble ash are not more than $4.65 \% \pm$ $0.06 \%$ and $0.13 \% \pm 0.04 \%$.

3. Extracts of calamondin peel from three regions namely Bukittinggi, Padang and Pesisir Selatan have antibacterial activity against bacteria Staphylococcus aureus, Eschericia coli, Enterococcus faecalis, and Pseudomonas auruginosa at a concentration of $15 \%$ with a range of inhibitory diameters of $7.65 \mathrm{~mm} \pm 0.36 \mathrm{~mm}$ to $9.96 \mathrm{~mm} \pm 0.52 \mathrm{~mm}$ and at a concentration of $20 \%$ with a range of inhibitory diameter of $9.26 \mathrm{~mm} \pm 0.72 \mathrm{~mm}$ to $13.39 \mathrm{~mm} \pm 0.28 \mathrm{~mm}$.

\section{SUMMARY}

Research on the Standardization Study of Simplicia and Extract of Calamondin (Citrus microcarpa Bunge) Peel, Quantification of Hesperidin and Antibacterial Assay was carried out. Calamondin had antioxidant and Antibacterial activity.

\section{ACKNOWLEDGEMENTS}

The authors would like to deliver a special appreciation to the Dean of Faculty of Pharmacy of Universitas Andalas for the financial support based on Research Grant of faculty of Pharmacy Universitas Andalas.

\section{CONFLICTS OF INTEREST}

The author(s) declare(s) that there is no conflicts of interest regarding the publication of this article.

\section{REFERENCES}

1. Ramly F, Durani, Siswadi. Jeruk Varietas Kalamansi FR. 2012.

2. Dewi K, Mujiharjo S, Utama A. Potensi Pengolaan Hasil Samping Sirup Kalamansi Menuju "Zero Waste." Agroindustri. 2016;6(1):8-17.

3. Bhat R, Kamaruddin NSBC, Min-Tze L, Karim AA. Sonication improves kasturi lime (Citrus microcarpa) juice quality. Ultrason Sonochem. 2011;18(6):1295-300.

4. Yulliasri J, Pratiwi, Agusta A. Komponen Kimia dan Efek Antibakteri Minyak Atsiri Kulit Buah dan Daun Jeruk Kasturi (Citrus microcarpa Bunge.). Maj Farm Indones. 2000;11(1):77-85.

5. Cheong MW, Zhu D, Sng J. Characterisation of calamansi (Citrus microcarpa). Part II: Volatiles, physicochemical properties and non-volatiles in the juice. Food Chem. 2012;134(2):696-703.
6. Bhat R, Nor S, Che K, Liong M, Karim. Sanication Improves Kasturi Lime (Citrus Microcarpa) Juice Quality. Ultras Sonochemistry. 2011;18:1295-300.

7. Jacob R, Hasegawa S, Manners G. The Potential of Citrus Limonoids as Anticancer Agents. Perishables Handing Quartely. 2000:102.

8. Hamideh P, Ali R, Fatemeh S, Ramin R. Antioxidant and Antiinflammatory Properties of Citrus Flavonoids Hesperidin and Hesperidin. Phytother. 2014.

9. Adam H, Edy M, Ratna A. Hesperidin Meningkatkan Efek Sitotoksik Doxorubicin pada Sel MCF-7. Maj Farm Indones. 2010;21(1):8-17.

10. Health V. Seluk Beluk Food Suplemen. Jakarta: Gramedia; 2004

11. Osama M, Ayman M, Adel A, Mohamed B. Antidiabetic Effects of Hesperidin and Naringin in Type 2 Diabetic Rats. Diabetol Croat. 2012;41(2):53-67.

12. Bylka W, Matlawska I, Pilewski. Natural Flavonoids as Antimicrobial Agents. JANA. 2004;7(2):24-31.

13. Darius, Hidaiyanti R. Karakteristik Sirup Jeruk Kalamansi dengan Level Konsentrasi Gula Dan Bahan Penstabil Berbeda. 2018;(October).

14. Lee SW, Najiah M. Antimicrobial Property of 2-Hydroxypropane-1,2,3Tricarboxylic Acid Isolated from Citrus microcarpa Extract. Agric Sci China. 2009;8(7):880-6.

15. Alinejhad D, Asayesh MA, Asayes M. Determination of the Anti-inflammatory Property of Tannins from the Rind of Calamansi (Citrus microcarpa, Rutaceae). J Int Oral Heal. 2016;8(5):546-33.

16. Gede WP. Konservasi Citrus spp. di Kebun Raya Bali serta Potensi Pemanfaatannya. J Trop Agroecotechnology. 218AD;7(3):326-34.

17. Surlitah S. Perbaikan Profil Lipid pada Perempuan Dewasa Kelebihan Berat Badan Setelah Intervensi Sari Jeruk Kalamansi (Citrus microcarpa). J Gizi dan Pangan. 2017;12(2):93-100.

18. Saifudin A, Rahayu, Teruna H. Standardisasi Bahan Obat Alam. Yogyakarta: Graha IImu; 2011.

19. World Health Organization. Quality Control Methods for Medicinal Plant Materials. 1998.

20. Departemen Kesehatan RI. Farmakope Herbal Indonesia. 1st ed. Jakarta: Departemen Kesehatan RI; 2008.

21. Association APH. Standard Methods for the Examination of Water and Wastewater. 22nd ed. Washington DC; 2012.

22. Badan POM RI. Pedoman Teknologi Formulasi Sediaan Berbasis Ekstrak Jakarta: Badan POM RI; 2012.

23. Departemen Kesehatan RI. Parameter Standar Umum EkstrakTumbuhan Obat 2000.

24. Harborne J. Metode Fitokimia Penuntun Cara Modern Menganalisa Tumbuhan 2nd ed. (K, Padinawinata dan I S, ed.). Bandung: ITB; 1987.

25. Aventi A. Penelitian Pengukuran Kadar Air Buah. Pros Semin Nas. 2016.

26. Saifuddin A, Viessa R, Hilwan Y. Standarisasi Bahan Obat Alam. Yogyakarta: Graha IImu; 2011.

27. Winarno. Kimia Pangan Dan Gizi. Jakarta: PT Gramedia Pustaka Umum; 2004.

28. Nagasako-Akazome Y. Safety of High and Long-Term Intake of Polyphenols. Vol 1. Elsevier Inc.; 2013

29. Kementerian Kesehatan RI. Suplemen II Farmakope Herbal Indonesia. Jakarta: Direktorat Jenderal Bina Kefarmasian dan Alat Kesehatan; 2011.

30. Sylvia T, Pratiwi. Mikrobiologi Farmasi. Yogyakarta: PT Gelora Aksara Pratama 2008.

31. Atlas R. Handbook of Microbiological Media. 2nd ed. Boca Raton: CRC Press; 1996.

32. Novak K. Drug Facts and Comparisons. 56th ed. Missouri: Wolters KluwerHealth; 2002

33. Katzung B. Farmakologi Dasar Dan Klinik. Jakarta: EGC; 1994.

34. Lunggana I. Minuman Isotonik Pengganti Energi. Jakarta: Republika Online; 2002.

35. Haris A, Arniati, Werorilangi S. Uji Antibakteri Patogen Ekstrak Sponge Menggunakan Metode High Troughput Screening (HTS) dengan indikator MTT (3-[4,5-dimethylthiazol- 2-yl]-2,5-diphenyltetrazolium bromide). 2004:1-14. 


\section{GRAPHICAL ABSTRACT}

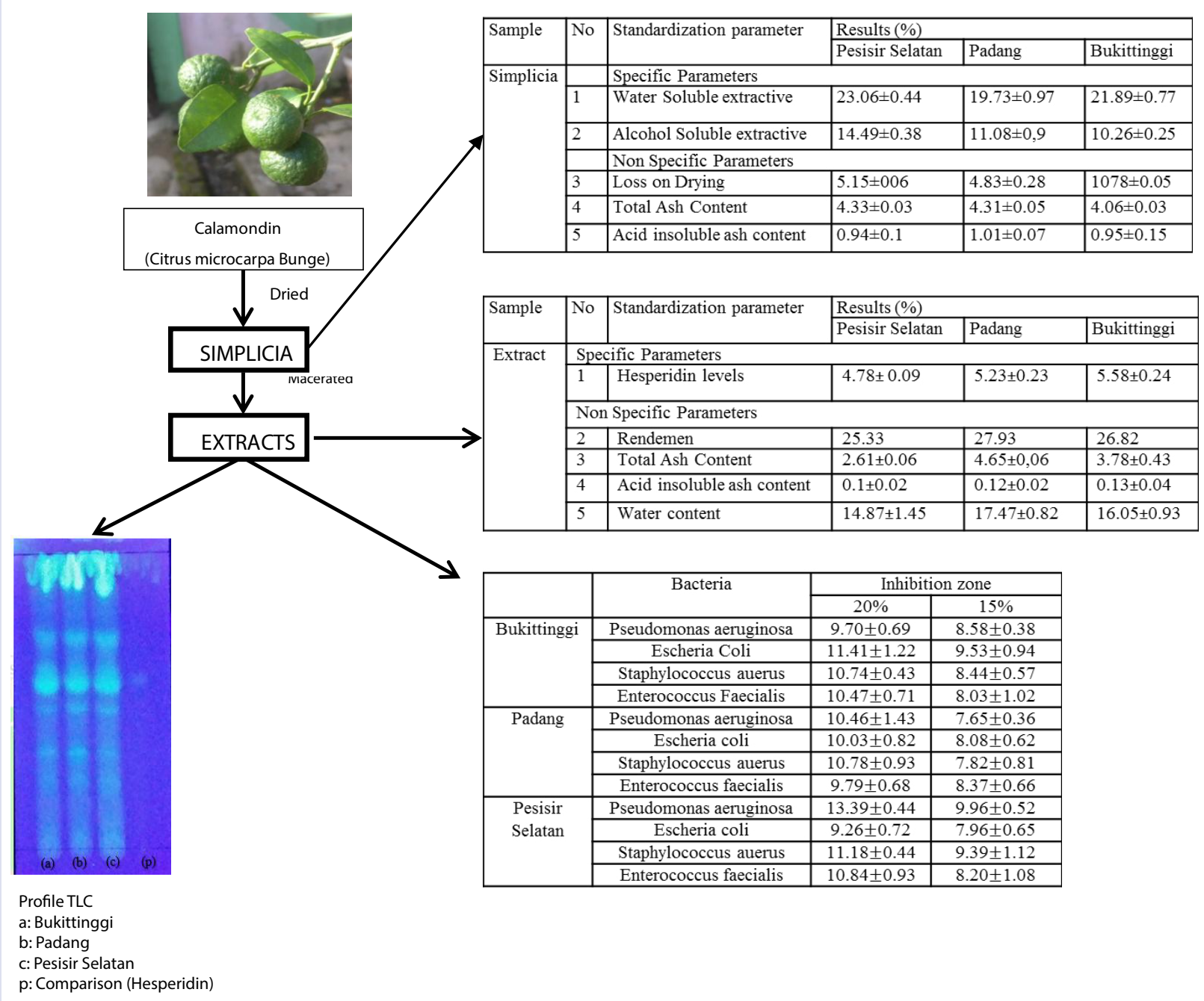

\section{ABOUT AUTHORS}

- Dr. Elidahanum Husni, M.Si, Apt.: Currently, as a lecturer at the Faculty of Pharmacy, University Andalas. Graduated from Faculty of Pharmacy Universitas Andalas in 1986, then Master Program in 1995 at School of Pharmacy Institut Teknologi Bandung (ITB Bandung) and Doctoral Program in Department Biomedical, Faculty of Medicine, University Andalas in 2015. The research and expertise are Pharmacognosy.

- Dr. Friardi Ismed, Apt.: Graduated Faculty of Pharmacy Universitas Andalas, Indonesia (B.Sc. Hons.; 2004); Universite de Rennes 1, France (Doktoral, 2012). Currently, as a lecturer at the Faculty of Pharmacy, since 2015. Research interests are natural product chemistry and medicinal chemistry, including Sumatran medicinal plants.

- Dony Afriyandi, S.Farm: Graduate student in Faculty of Pharmacy Universitas Andalas who involved in assisting the research and collecting data.

Cite this article: Husni E, Ismed F, Afriyandi D. Standardization Study of Simplicia and Extract of Calamondin (Citrus microcarpa Bunge) Peel, Quantification of Hesperidin and Antibacterial Assay. Pharmacogn J. 2020;12(4):777-83. 